\title{
Prostaglandins mediate bradykinin-induced reduction of exhaled nitric oxide in asthma
}

\author{
S.A. Kharitonov, M.M. Sapienza, K.F. Chung, P.J. Barnes
}

Prostaglandins mediate bradykinin-induced reduction of exhaled nitric oxide in asthma. S.A. Kharitonov, M.M. Sapienza, K.F. Chung, P.J. Barnes (C) ERS Journals Ltd 1999. ABSTRACT: Bradykinin (BK) is a mediator of inflammation in asthma with potent bronchoconstrictor actions. Endogenous release of nitric oxide may inhibit BK-induced bronchoconstriction. This study investigated whether bradykinin inhalation could modulate exhaled NO levels in normal and asthmatic subjects, and whether the bradykinin-induced effects were mediated through the production of cyclo-oxygenase products in patients with asthma, by studying the effect of the cyclo-oxygenase inhibitor, L-acetylsalicylic acid (L-ASA).

Exhaled NO concentration and forced expiratory volume in one second (FEV1) were measured by chemiluminescence following inhalation of increasing concentrations of BK.

In asthmatics $(\mathrm{n}=11)$, BK induced a dose-dependent decrease in exhaled NO concentration from $21.3 \pm 1.6$ to $6.0 \pm 0.5$ parts per billion $(\mathrm{ppb})(\mathrm{p}<0.01)$ at the highest concentration, associated with a significant fall in FEV1. In normal subjects $(n=10)$, the exhaled NO concentration fell from $7.2 \pm 0.13$ to $4.3 \pm 0.51 \mathrm{ppb}(\mathrm{p}<0.001) 15 \mathrm{~min}$, after a single inhalation of BK, but without a significant change in FEV1. In asthmatic subjects, pretreatment with inhaled $\mathrm{L}-\mathrm{ASA}\left(90 \mathrm{mg} \cdot \mathrm{mL}^{-1}, 4 \mathrm{~mL}\right)$ did not alter exhaled NO levels, but prevented a BK-induced fall in exhaled NO concentration, as indicated by a significant increase in exhaled NO levels at the provocative concentration of BK causing a 20\% fall in FEV1, $(5.7 \pm 0.94 \mathrm{ppb}$ after placebo and 12.0 $\pm 1.8 \mathrm{ppb}$ after LASA; $\mathbf{p}<0.05$ ). L-ASA significantly reduced bronchial responsiveness to BK 3.9-fold $(\mathbf{p}<0.01)$.

Inhaled bradykinin induced bronchoconstriction and a reduction in exhaled nitric oxide levels in asthmatic subjects, an effect that is partly mediated by cyclo-oxygenase products.

Eur Respir J 1999; 14: 1023-1027.

Nitric oxide is formed from L-arginine by NO synthase (NOS) in many cells within the respiratory tract and may play an important role in the pathophysiology of airway diseases $[1,2]$. NO can be detected in exhaled air [3] and is increased in patients with asthma $[4,5]$. The sources of exhaled NO in asthma are not entirely clear but include the airway epithelium, which demonstrates increased expression of the inducible NOS (iNOS) [6]. Other isoforms of NOS [7] such as those expressed in endothelial cells and neurons may contribute to a lesser extent to exhaled NO levels.

Bradykinin (BK) is a mediator formed in the airway mucosa from plasma kininogens [8] and is a potent bronchoconstrictor in asthmatic patients, but not in normal individuals $[9,10]$. BK can induce the release of the bronchodilator prostaglandin $(\mathrm{PG}) \mathrm{E}_{2}$ from epithelial and airway smooth muscle cells [11]. Therefore, the overall effect of BK could depend on the balance between the direct effect of BK and the induced release of the bronchodilator, $\mathrm{PGE}_{2}$. However, other factors may also be important. Thus, NO is also involved because BK-induced bronchoconstriction is worsened by NOS inhibitors [12]; in addition, $\mathrm{PGE}_{2}$ and $\mathrm{PGF}_{2 \alpha}$, inhibit exhaled $\mathrm{NO}$ in patients with asthma [13]. Thus, BK-induced bronchoconstriction could be mediated by a complex interaction between NO and PGs.
Dept of Thoracic Medicine, Imperial College School of Medicine at the National Heart and Lung Institute, London, UK.

\section{Correspondence: KF Chung}

Thoracic Medicine

Imperial College School of Medicine at the National Heart and Lung Institute

Dovehouse Street

London 6LY SW3

UK

Fax: 1713518126

Keywords: Airway inflammation asthma bradykinin exhaled nitric oxide prostaglandins

Received: October 211998

Accepted after revision July 211999

Supported by the British Lung Foundation (UK).
The effect of inhaled BK on exhaled NO levels is not known. In preliminary studies of patients with asthma, it was found that BK induced a fall in exhaled NO levels, and this study, therefore, examined whether this fall could occur through the endogenous production of PGs induced by BK inhalation. The ability of a cyclo-oxygenase inhibitor, L-acetylsalicylic acid (L-ASA), to modulate endogenous NO production induced by BK in patients with asthma was investigated. To examine further the relationship between exhaled NO levels and airway calibre, the forced expiratory volume in one second (FEV1) was also measured. Additionally, the effect of BK on exhaled NO levels in asthmatics were compared with those in normal nonasthmatic subjects by studying an additional group of normal volunteers.

\section{Methods}

Subjects

The characteristics of the nonsmoking, non-aspirinsensitive asthmatics and normal volunteers are shown in table 1. The provocative concentration of substance causing a $20 \%$ fall in FEV1 (PC20) to methacholine was measured as described previously [14]. No subjects were taking inhaled or oral corticosteroids. All asthmatics were using occasional $\beta_{2}$-agonists and had been in a stable 
Table 1. - Characteristics of subjects

\begin{tabular}{llcccc}
\hline $\begin{array}{l}\text { Subjects } \\
\mathrm{n}\end{array}$ & $\begin{array}{c}\text { Sex } \\
\mathrm{F} / \mathrm{M}\end{array}$ & $\begin{array}{c}\text { Age } \\
\text { yrs }\end{array}$ & $\begin{array}{c}\text { Atopy } \\
\mathrm{n}\end{array}$ & $\begin{array}{c}\text { FEV1 } \\
\% \text { pred }\end{array}$ & $\begin{array}{c}\mathrm{PC}_{20} \\
\mathrm{mg} \cdot \mathrm{mL}^{-1}\end{array}$ \\
\hline Control & $2 / 8$ & $30 \pm 5$ & 0 & $101 \pm 5$ & $>16$ \\
Asthma & $1 / 10$ & $31 \pm 6$ & 11 & $95 \pm 5$ & $0.44 \pm 0.09^{*}$ \\
\hline
\end{tabular}

Data are presented as mean \pm SEM except for provocative concentration of methacholine causing a $20 \%$ fall in forced expiratory volume in one second (FEV1) (PC20). F: female; M: male; atopy: positive immediate skin test to one or more aeroallergens.

condition for $\geq 2$ months prior to entering the study. The study was approved by the Ethics Committee of the Royal Brompton Hospital.

\section{Protocols}

There were two separate protocols: 1) Normal subjects attended the laboratory on two separate morning visits, $\geq 7$ days apart, for inhalation of BK $\left(2.5 \mathrm{mg} \cdot \mathrm{mL}^{-1}, 5\right.$ breaths $)$ or matched nebulized placebo with the same diluent administered in a double-blind and random order. 2) Asthmatic subjects attended the laboratory on two separate morning visits, $\geq 7$ days apart, in order to undertake concentration/response studies with BK, after receiving either nebulized L-ASA or placebo administered in a doubleblind and random order $15 \mathrm{~min}$ prior to BK challenge. NO measurements were made by a technician unaware of the protocol involved.

\section{Bradykinin challenge}

Following baseline FEV1 measurement, subjects inhaled five breaths $0.9 \% \mathrm{NaC} 1$ via a breath-activated nebulizer (Dosimeter MB3; MEFAR Electromedical, Bovezzo, Italy) with an output of $16 \mu \mathrm{L} \cdot$ breath $^{-1}$ (inhalation time $1 \mathrm{~s}$, breathholding time $6 \mathrm{~s}$ ). BK (Sigma Chemical Company, Poole, UK) was freshly prepared in $10 \%$ ethanol in $0.9 \% \mathrm{NaCl}$ in order to produce a stock solution of 8 $\mathrm{mg} \cdot \mathrm{mL}^{-1}$ and then diluted with $0.9 \% \mathrm{NaC} 1$ to concentrations of $0.02-5.12 \mathrm{mg} \cdot \mathrm{mL}^{-1}$, and was used within $30 \mathrm{~min}$. The aerosol was inhaled in increasing doubling concentrations from end-tidal volume to full inspiratory capacity. FEV1 was measured 2 min after each inhalation. The challenge was stopped when there was a fall of $>20 \%$ in FEV1. The PC20 to BK was calculated by linear interpolation of the logarithmic dose/response curve.

Exhaled NO levels were measured before and after $0.9 \%$ $\mathrm{NaC} 1$ inhalation, and the mean of the two measurements was taken as baseline. Exhaled NO concentration was measured every 4 min after inhalation of each concentration of BK and for 20 min thereafter during spontaneous recovery after the highest concentration. For normal subjects, one concentration of BK $\left(2.5 \mathrm{mg} \cdot \mathrm{mL}^{-1}\right.$, five breaths $)$ or its diluent was administered, and FEV1 and NO were measured every $5 \mathrm{~min}$ for $40 \mathrm{~min}$ and then every $10 \mathrm{~min}$ up to $60 \mathrm{~min}$.

\section{Administration of L-acetylsalicylic acid}

After a 15-min rest, baseline measurements of FEV1 and NO were made, followed by inhalation of nebulized LASA (Laboratories Synthelabo, Synthelabo Group, Le Plessis Robinson, France; $90 \mathrm{mg} \cdot \mathrm{mL}^{-1}, 4 \mathrm{~mL} ; 526 \mathrm{mOsm} \cdot \mathrm{L}^{-1}$, $\mathrm{pH}$ 5.24) or nebulized vehicle alone (glycine solution 30 $\mathrm{mg} \cdot \mathrm{mL}^{-1}, 4 \mathrm{~mL}, 503 \mathrm{mOsm} \cdot \mathrm{L}^{-1}$, pH 5.91 in $0.9 \% \mathrm{NaC} 1$ adjusted to the same $\mathrm{pH}$ and tonicity as the L-ASA). The aerosols were generated from a starting volume of $4 \mathrm{~mL}$ in a Sidestream $\mathbb{R}$ nebulizer (Medic-Aid, Pagham, UK) driven by Porta-Neb 50 (Medic-Aid, Pagham, UK) (flow $6.5 \mathrm{~L} \cdot \mathrm{min}^{-1}$ dynamic pressure $97 \mathrm{kPa}$ ), and inhaled to dryness by tidal breathing over a 10-12-min time-period. The same nebulizer was used for all asthmatic subjects. Further FEV1 and NO measurements were repeated after $15 \mathrm{~min}$.

\section{Measurement of exhaled nitric oxide}

Exhaled NO was measured using a chemiluminescence analyser (Model LR2000; Logan Research, Rochester, UK), with a sensitivity range of $1-5,000$ parts per billion (ppb) NO, an accuracy of $\pm 0.5 \mathrm{ppb}$ and a response time of $<2 \mathrm{~s}$ to $90 \%$ of full scale. The analyser also measured carbon dioxide (range $0-10 \% \mathrm{CO}_{2}$, accuracy $\pm 0.1 \%$, response time $200 \mathrm{~ms}$ to $90 \%$ of full scale), expiratory flow and pressure, and exhaled volume in real-time. It was fitted with a biofeedback display unit to provide visual guidance to the subject in maintaining a given range of pressure and exhalation flow $\left(0.40 \pm 0.05 \mathrm{kPa}, 5-6 \mathrm{~L} \cdot \mathrm{min}^{-1}\right)$ for endexhaled NO measurements $[15,16]$.

The analyser was calibrated weekly using three different gases, a certified concentration of $\mathrm{NO}$ in nitrogen of 90 $\mathrm{ppb}$, and $436 \mathrm{ppb}$ and certified 5\% $\mathrm{CO}_{2}$ (BOC Special Gases, Guildford, UK).

\section{Data analysis}

Results were expressed as means \pm SEM, apart from PC20 which were expressed as geometric means and geometric SEM. Comparisons between treatments were made by repeated-measures two-way analysis of variance (ANOVA). The effect of L-ASA on the PC20 and on exhaled NO was examined by the paired Student's t-test. A p-value $<0.05$ was considered significant.

In order to examine the effect of placebo or BK on the time-dependent changes in FEV1, and exhaled NO, a repeated-measurements two-way ANOVA was used. In order to determine at which time periods there had been a significant change, a paired t-test with the Bonferroni correction was performed. To examine the effect of L-ASA, from each concentration/exhaled NO response, the level of exhaled NO at the PC20 to bradykinin for that response was determined. This value was taken as an overall representation of the response. A paired t-test was performed on these values, comparing the effect of placebo with L-ASA. A p-value $<0.05$ was considered significant.

\section{Results}

\section{Normal subjects}

BK $\left(2.5 \mathrm{mg} \cdot \mathrm{mL}^{-1}\right)$ caused a rapid reduction in exhaled NO levels in normal subjects (from $7.2 \pm 0.13$ to $4.3 \pm 0.51$ $\mathrm{ppb}$ at $15 \mathrm{~min} \mathrm{p}<0.001)$, an effect that persisted for up to 50 min $(6.0 \pm 0.40 \mathrm{ppb}, \mathrm{p}<0.05$; fig. 1$)$. Inhalation of diluent alone caused no significant changes in exhaled NO levels (fig. 1a). There were no significant changes in exhaled NO concentrations following repeated forced exhalation manoeuvres (FEV1), as shown by the effect of placebo (fig 1b). 

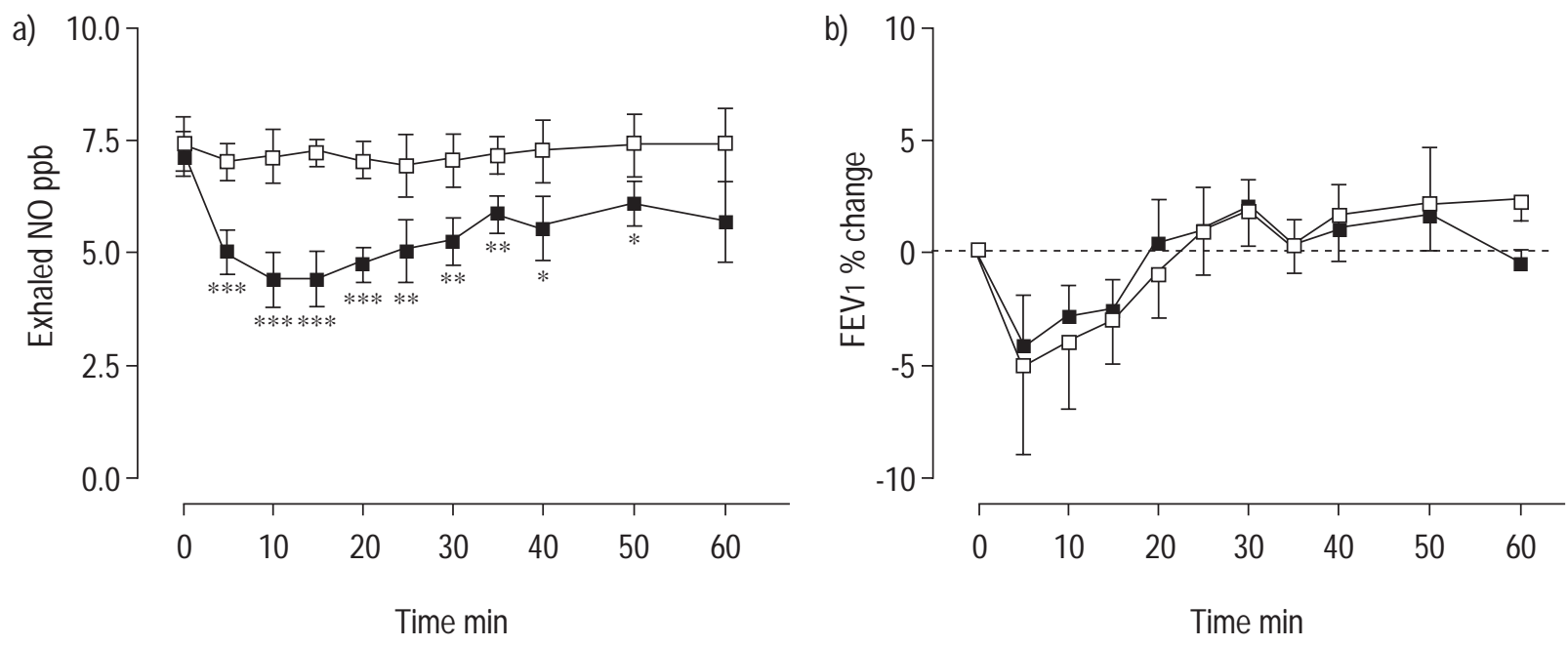

Fig. 1. - Time course of exhaled nitric oxide and forced expiratory volume in one second (FEV1) following a single dose of bradykinin $\left(2.5 \mathrm{mg} \cdot \mathrm{mL}^{-1}\right.$,

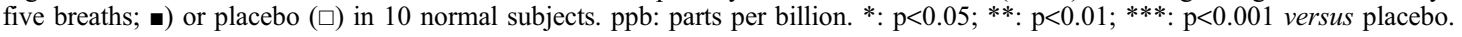

\section{Asthmatic subjects}

Inhaled L-ASA and placebo caused small but nonsignificant reductions in exhaled NO level (from 20.7 \pm 1.9 to $17.6 \pm 1.3 \mathrm{ppb}$ and from $22.3 \pm 1.9$ to $21.3 \pm 1.6 \mathrm{ppb}$, respectively) and in FEV1 (from $3.7 \pm 0.1$ to $3.4 \pm 0.2 \mathrm{~L}$ and from $3.7 \pm 1.0$ to $3.5 \pm 0.2 \mathrm{~L}$; respectively). Following placebo, BK produced concentration-dependent falls in exhaled NO concentration, with a reduction in NO concentration from $21.3 \pm 1.6 \mathrm{ppb}$ at baseline to $6.0 \pm 0.5 \mathrm{ppb}(\mathrm{p}<0.01)$ at the highest concentration of BK (fig. 2a). Inhaled L-ASA attenuated the BK-induced fall in NO concentration. For example, after L-ASA, BK caused a significant reduction in exhaled NO level at concentrations of $0.64,1.28$ and $2.56 \mathrm{mg} \cdot \mathrm{mL}^{-1}$ of BK (fig. 2). Following placebo, the level of exhaled $\mathrm{NO}$ at the $\mathrm{PC} 20$ to bradykinin was $5.7 \pm 0.94$ $\mathrm{ppb}$, whereas after L-ASA, it was $12.0 \pm 1.76 \mathrm{ppb}(\mathrm{p}<0.01)$ (fig. 2b). Thus, L-ASA caused a significant attenuation of the BK-induced fall in NO concentration at comparable

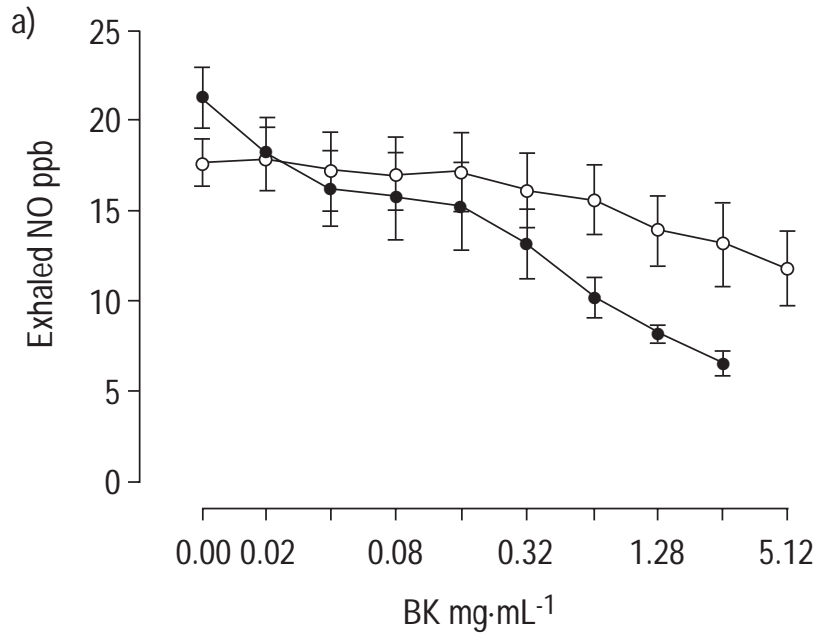

levels of bronchoconstriction. L-ASA also protected against BK-induced bronchoconstriction with an increase in $\mathrm{PC} 20$ to BK from $0.70 \pm 0.40$ (geometric mean $\pm_{\mathrm{GSEM}}$ ) to $2.72 \pm 0.67 \mathrm{mg} \cdot \mathrm{mL}^{-1}(\mathrm{p}<0.01)$ (fig. 3). Both exhaled NO level and FEV1 returned to baseline within $20 \mathrm{~min}$ of the beginning of the recovery period.

\section{Discussion}

Inhaled BK induced a dose-dependent fall in exhaled NO levels in patients with asthma with a maximum reduction of $70 \%$, while the single dose of BK also caused a reduction in exhaled NO concentration in normal subjects. Although the fall in exhaled NO concentration was not accompanied by a reduction in FEV1 in normal subjects, both FEV1 and NO levels were reduced by BK in asthmatic patients. In patients with asthma, the fall in exhaled NO concentration induced by BK was markedly attenuated by pretreatment with a cyclo-oxygenase inhibitor, L-ASA, which itself did not change baseline exhaled NO levels.

\section{b)}

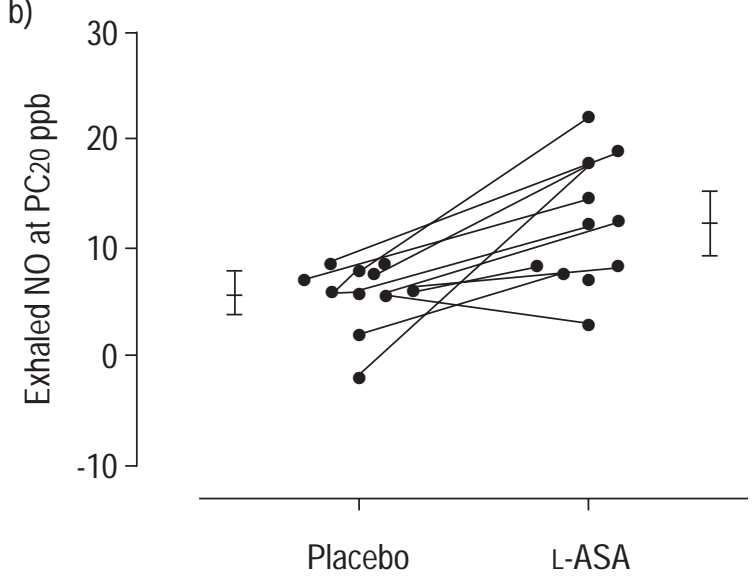

Fig. 2. - a) Concentration/response curve of exhaled nitric oxide to inhaled bradykinin (BK) in 11 ashmatic subjects pretreated with either L-acetylsalicylic acid (L-ASA; $(\bigcirc)$ or placebo $(\bullet)$. At BK concentrations of 1.28 and $2.56 \mathrm{mg} \cdot \mathrm{mL}^{-1}$, there were seven and four paired data, respectively. b) Exhaled NO concentration at the provocative concentration of BK causing a $20 \%$ fall in forced expiratory volume in one second (PC20) after placebo or L-ASA pretreatment in individual subjects. For the same degree of bronchoconstriction, L-ASA increased exhaled NO levels significantly (p<0.01). The horizontal and vertical bars represent mean \pm SEM. ppb: parts per billion. 

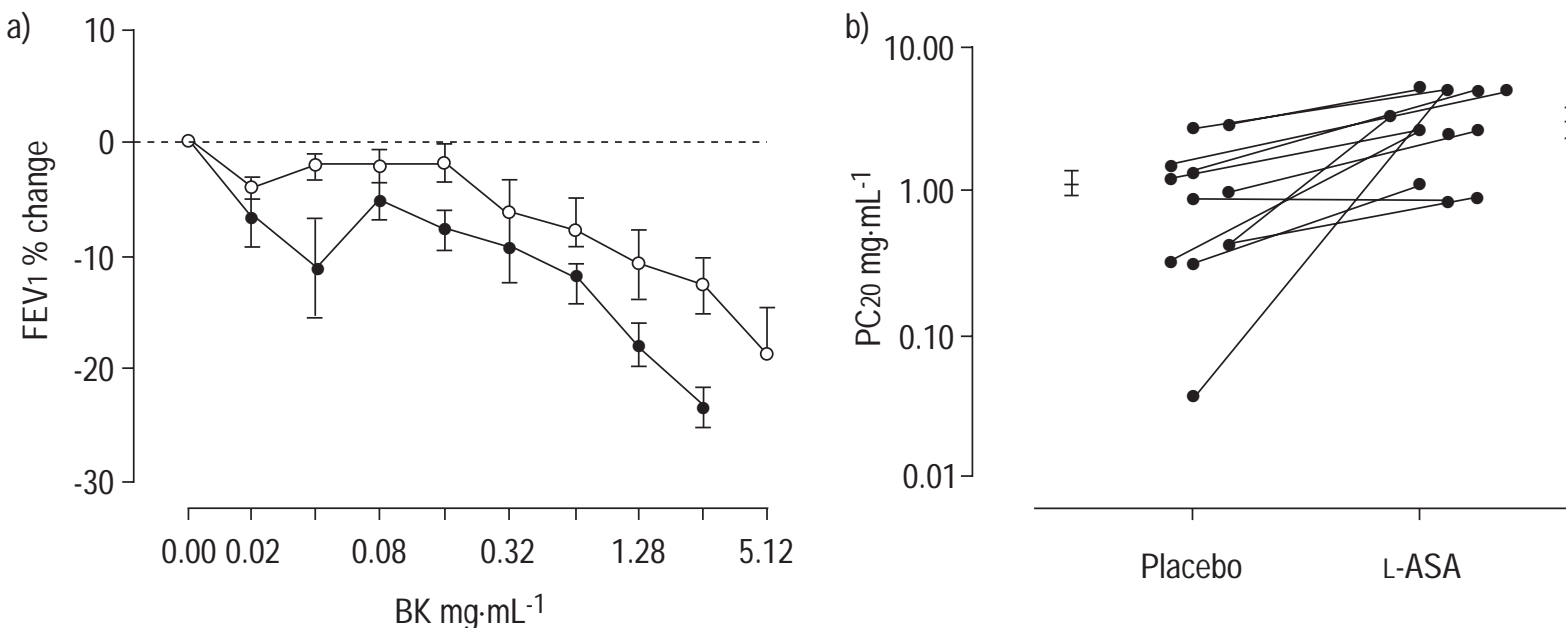

Fig. 3. - a) Concentration/response curve of forced expiratory volume in one second (FEV1) to inhaled bradykinin (BK) in 11 asthmatic subjects pretreated with L-ASA $(O)$ or placebo $(\bullet)$. b) Provocative concentration of BK causing a $20 \%$ fall in FEV1 after placebo or L-ASA pretreatment in individual subjects. L-ASA caused a significant increase in $\mathrm{PC} 20(\mathrm{p}<0.01)$. The horizontal and vertical bars represent mean \pm SEM.

L-ASA also attenuated BK-induced bronchoconstriction. These results indicate that $\mathrm{BK}$ induced the release of cyclooxygenase products which in turn reduced exhaled NO levels.

BK up-regulates the inducible cyclo-oxygenase enzyme, cyclo-oxygenase-2, in airway epithelial cells [11] and in airway smooth muscle cells [17], and stimulates PG synthesis and release from many cell types including epithelial cells $[18,19]$. In turn, the cyclo-oxygenase product, $\mathrm{PGE}_{2}$, may prevent the induction of iNOS, as has been reported in certain cell lines in vitro [20]. $\mathrm{PGE}_{2}$ and $\mathrm{PGF}_{2 \alpha}$ are two cyclo-oxygenase products known to reduce exhaled NO levels [13]. Thus, BK may cause a reduction in exhaled NO levels by inhibiting iNOS expression in airways, through the induction of cyclo-oxygenase products such as $\mathrm{PGE}_{2}$. However, because the effect of BK on exhaled NO levels occurred within a few minutes, it is most likely that there was already an upregulation of cyclo-oxygenase expression in the airways of patients with asthma, which was directly activated by BK. For example, BK can induce the release of $\mathrm{PGE}_{2}$ rapidly from airway epithelial cells in vivo once the cyclooxygenase enzyme has been activated by interleukin- $1 \beta$ [21]. Compatible with the effect of BK in inhibiting cyclo-oxygenase activity is the observation that $\mathrm{BK}$ reduced asthmatic NO levels to within the range found in normal subjects. The reduction in exhaled NO concentration observed in those asthmatics following BK treatment was similar to that reported following the inhalation of aminoguanidine, an inhibitor of iNOS [22]. The inhibitory effect of BK on exhaled NO in normal subjects was less than that observed in asthmatics, which is likely to be due to the amount of iNOS present in these subjects compared to asthmatics [6]. Alternatively, it is possible that BK may inhibit other forms of NOS in the airways of normal subjects, while having a predominant effect on iNOS upregulation in asthmatic patients.

The cyclo-oxygenase inhibitor, L-ASA, significantly protected against BK-induced bronchoconstriction. Previous studies have failed to demonstrate any effect of other inhibitors of cyclo-oxygenase, possibly because these inhibitors were administered orally $[9,10]$. The present data indicate that the modulation of endogenous NO level in patients with asthma may be directly related to changes in airway calibre. Thus, the reversal of the fall in endogenous NO concentration by L-ASA may have led to protection against BK-induced bronchoconstriction. This possibility is supported by the report that inhibition of endogenous NO production by the NOS inhibitor, $N^{\mathrm{G}}$ mono-methyl-L-arginise (L-NMMA), enhanced BK-induced bronchoconstriction in asthmatics [12]. These results, taken together, indicate that endogenous NO may protect against $\mathrm{BK}$-induced bronchoconstriction through the activation of $\mathrm{PGE}_{2}$. Exogenously administered $\mathrm{NO}$ has poor bronchodilator and bronchoprotective properties in man [23], which may be due to the failure of exogenous NO to reach the airway smooth muscle in sufficient quantities. An alternative explanation for the observed effect could relate to the potential modulation by NO of bronchial blood flow [24, 25], which in turn could influence the deposition of inhaled drugs and/or airway calibre [26].

In a previous study, falls in exhaled NO concentration were reported following bronchoconstrictor challenges with histamine, adenosine monophosphate and hypertonic saline in patients with asthma [27], indicating that bronchoconstriction itself may cause a reduction in exhaled NO levels. However, it has previously been shown that bronchoconstriction with methacholine was not accompanied by falls in exhaled NO concentration [28], and, in the present study, a fall in exhaled NO concentration was observed after BK treatment in normal subjects, who did not demonstrate bronchoconstriction. In addition, it was shown that, at similar levels of bronchoconstriction induced by BK, L-ASA significantly reduced exhaled NO levels. Thus, the link between airway calibre and exhaled NO concentration is not a direct one. Rather, the authors believe that changes in exhaled NO level are likely to also involve direct modulation of NO production by the inhaled provoking stimulus, which also happens to cause bronchoconstriction. For example, in the studies of DE Gouw and coworkers [27, 29], histamine may be the common factor modulating NO production since the two indirect stimuli used, adenosine and hypertonic saline, are histamine-dependent $[30,31]$. Further studies are necessary to elucidate these mechanisms. 
The role played by endogenous NO in asthmatic inflammation is not known. Pro-inflammatory roles have been attributed to NO, such as the induction of eosinophil chemotaxis or increase in microvascular leakage $[1,32]$, but the present study supports a bronchoprotective effect of NO. Therefore, NO could play both pro-inflammatory and bronchoprotective roles in asthma.

In summary, it has been shown that cyclo-oxygenase products mediate the fall in exhaled nitric oxide levels induced by bradykinin in patients with asthma. The data indicate that endogenous nitric oxide release may have some bronchoprotective effects.

\section{References}

1. Barnes PJ, Belvisi MG. Nitric oxide and lung disease Thorax 1993; 48: 1034-1043.

2. Gaston B, Drazen JM, Loscalzo J, Stamler JS. The biology of nitrogen oxides in the airways. Am J Respir Crit Care Med 1994; 149: 538-551.

3. Gustafsson LE, Leone AM, Persson MG, Wilklund NP, Moncada S. Endogenous nitric oxide is present in the exhaled air of rabbits, guinea pigs and humans. Biochem Biophys Res Commun 1991; 181: 852-857.

4. Kharitonov SA, Yates DH, Robbins RA, Logan-Sinclair R, Shinebourne EA, Barnes PJ. Increased nitric oxide in exhaled air of asthmatic patients. Lancet 1994; 343: 133-135.

5. Alving K, Weitzberg E, Lundberg JM. Increased amount of nitric oxide in exhaled air of asthmatics. Eur Respir $J$ 1993; 6: 1368-1370.

6. Hamid Q, Springall DR, Riveros-Moreno V, et al. Induction of nitric oxide synthase in asthma. Lancet 1993; 342: 1510-1513.

7. Kobzik L, Bredt DS, Lowenstein CJ, et al. Nitric oxide synthase in human and rat lung: immunocytochemical and histochemical localization. Am J Respir Cell Mol Biol 1993; 9: 371-377.

8. Barnes PJ. Bradykinin and asthma. Thorax 1992; 47: 979-983.

9. Fuller RW, Dixon CMS, Cuss FMC, Barnes PJ. Bradykinin-induced bronchoconstriction in humans mode of action. Am Rev Respir Dis 1987; 135: 176-180.

10. Polosa R, Holgate ST. Comparative airway responses to inhaled bradykinin, kallidin and [des Arg9]-bradyikinin in normal and asthmatic airways. Am Rev Respir Dis 1990; 142: 1367-1371.

11. Bramley AM, Samhoun MN, Piper PJ. The role of epithelium in modulating the responses of guinea-pig trachea induced by bradykinin in vitro. Br J Pharmacol 1990; 99: $762-766$.

12. Ricciardolo FLM, Geppetti P, Mistretta A, et al. Randomised double-blind placebo-controlled study of the effect of inhibition on nitric oxide synthesis in bradykinin-induced asthma. Lancet 1996; 348: 374-377.

13. Kharitonov SA, Sapienza MA, Barnes PJ, Chung KF. Prostaglandins $E_{2}$ and $F_{2 \alpha}$, reduce exhaled nitric oxide in normal and asthmatic subjects irrespective of airway calibre changes. Am J Respir Crit Care Med 1998; 158: 1374-1378.

14. Kharitonov SA, O'Connor BJ, Evans DJ, Barnes PJ. Allergen-induced late asthmatic reactions are associated with elevation of exhaled nitric oxide. Am J Respir Crit Care Med 1995; 151: 1894-1899.

15. Kharitonov SA, Chung FK, Evans DJ, O'Connor BJ, Barnes PJ. The elevated level of exhaled nitric oxide in asthmatic patients is mainly derived from the lower res- piratory tract. Am J Respir Crit Care Med 1996; 153 : 1773-1780.

16. Kharitonov SA, Alving K, Barnes PJ. Exhaled and nasal nitric oxide measurements. recommendations. Eur Respir $J$ 1997; 10: 1683-1693.

17. Pavord ID, Wong CS, Williams J, Tattersfield AE. Effect of inhaled prostaglandin $\mathrm{E}_{2}$ on allergen-induced asthma. Am Rev Respir Dis 1993; 148: 87-90.

18. Leikauf GD, Ueki IF, Nadel JA, Widdicombe JH. Bradykinin stimulates $\mathrm{Cl}$ secretion and prostaglandin $\mathrm{E}_{2}$ release by canine tracheal epithelium. Am J Physiol 1985; 248: F48-F55.

19. Lerner UH, Modeer T. Bradykinin B1 and B2 receptor agonists synergistically potentiate interleukin-1-induced prostaglandin biosynthesis in human gingival fibroblasts. Inflammation 1991; 15: 427-436.

20. Tetsuka T, Daphna Iken D, Srivastava SK, Baier LD, DuMaine J, Morrison AR. Cross-talk between cyclooxygenase and nitric oxide pathways: prostaglandin $\mathrm{E}_{2}$ negatively modulates induction of nitric oxide synthase by interleukin 1. Proc Nati Acad Sci USA 1994; 91: 12168-12172.

21. Saunders MA, Belvisi MG, Cirino G, Barnes PJ, Warner TD, Mitchell JA. Mechanisms of prostaglandin $\mathrm{E}_{2}$ release by intact cells expressing cyclo-oxygenase-2: evidence for a "two-component" model. J Pharmacol Exp Ther 1999; 288: 1101-1106.

22. Yates DH, Kharitonov SA, Thomas PS, Barnes PJ. Endogenous nitric oxide is decreased in asthmatic patients by an inhibitor of inducible nitric oxide synthase. Am J Respir Crit Care Med 1996; 154: 247-250.

23. Hogman M, Frostell CG, Hedenstrom H, Hedenstierna G. Inhalation of nitric oxide modulates adult human bronchial tone. Am J Respir Crit Care Med 1993; 148: 1474 1478.

24. Charan NB, Johnson SR, Lakshminarayan S, Thompson WH, Carvalho P. Nitric oxide and beta-adrenergic agonist-induced bronchial arterial vasodilation. $J$ Appl Physiol 1997; 82: 686-692.

25. Carvalho P, Johnson SR, Charan NB. Non-cAMP-mediated bronchial arterial vasodilation in response to inhaled beta-agonists. J Appl Physiol 1998; 84: 215-221.

26. Widdicombe J. The tracheobronchial vasculature: a possible role in asthma. Microcirculation 1996; 3: 129-141.

27. de Gouw H, Hendriks J, Woltman AM, Twiss IM, Sterk PJ. Exhaled nitric oxide (NO) is reduced shortly after bronchoconstriction to direct and indirect stimuli in asthma. Am J Respir Crit Care Med 1998; 158: 315-319.

28. Kharitonov SA, O'Connor BJ, Evans DJ, Barnes PJ. Allergen-induced late asthmatic reactions are associated with elevation of exhaled nitric oxide. Am J Respir Crit Care Med 1995; 151: 1894-1899.

29. de Gouw H, Grunberg K, Schot R, Kroes AC, Dick EC, Sterk PJ. Relationship between exhaled nitric oxide and airway hyperresponsiveness following experimental rhinovirus infection in asthmatic subjects. Eur Respir $J$ 1998; 11: 126-132.

30. Finney MJ, Anderson SD, Black JL. Terfenadine modifies airway narrowing induced by the inhalation of nonisotonic aerosols in subjects with asthma. Am Rev Respir Dis 1990; 141: 1151-1157.

31. Rodwell LT, Anderson SD, Seale JP. Inhaled clemastine, an $\mathrm{H} 1$ antihistamine inhibits airway narrowing caused by aerosols of nonisotonic saline. Eur Respir J 1991; 4: 1126-1134.

32. Barnes PJ, Liew FY. Nitric oxide and asthmatic inflammation. Immunology Today 1995; 16: 128-130. 